\title{
THE IMPACT OF QUARTERLY EARNINGS ANNOUNCEMENTS ON STOCK PRICES
}

\section{Patryk Jagliński}

e-mail: patryk-jaglinski@o2.pl

ORCID: 0000-0001-9435-9281

(C) 2020 Patryk Jagliński

This work is licensed under the Creative Commons Attribution-ShareAlike 4.0 International License. To view a copy of this license, visit http://creativecommons.org/licenses/by-sa/4.0/

Quote as: Jagliński, P. (2020). The impact of quarterly earnings announcements on stock prices. Financial Sciences, 25(2-3).

DOI: $10.15611 /$ fins.2020.2.02

JEL Classification: G14, G18

\begin{abstract}
The post-earnings-announcement-drift (PEAD) is a long-standing market anomaly that is in conflict with the semi-strong form of market efficiency. The main aim of the article was to investigate how investors react to quarterly earnings announcements and to find out if the anomaly is present on the Warsaw Stock Exchange. An event study analysis for the period of 2017-2019 was conducted to answer these questions. Contrary to most other studies concerning the topic, no evidence was found for the existence of PEAD in the group of companies that reported earnings above the market expectations. The anomaly was only spotted in the group of companies that underachieved earnings forecasts. The author's concluding supposition is that the existence of the anomaly in the latter group is most likely due to the fact that short-selling is not widely available on the Polish stock exchange, and if the market participants had the tools necessary to counteract the anomaly, i.e. the possibility to take on short positions, it would not be present.
\end{abstract}

Keywords: market efficiency, quarterly earnings announcement, post-earnings-announcement-drift, PEAD, Warsaw Stock Exchange, WSE.

\section{Introduction}

Public companies release vast amount of information to the public, yet unarguably the financial results presented in the form of interim reports are among the most valuable. The announcement of a company's financial results that differ from market expectations can significantly impact the company's stock price. According to the efficient market hypothesis (EMH), it should be expected that investors closely follow companies' interim reports, and any unexpected changes in the level of earnings are accordingly reflected in the prices. What is more, in a semi-strong efficient market it should not be possible to earn abnormal returns on the basis of publicly available information. 
Post-earnings-announcement-drift (PEAD) is one of the longest standing market anomalies, whose existence contradicts the semi-strong form of market efficiency. The anomaly concerns companies that reported an unexpected change in earnings, and is the tendency for a stock's cumulative abnormal returns to drift in the direction of the earnings surprise for several weeks, or even months, following the announcement. This, in turn, allows investors to earn abnormal returns, by acting before the subsequent gradual adjustment of prices due to the announced earnings, occurs (Ball and Brown, 1968; Bernard and Thomas, 1989; Foster, Olsen and Shevlin, 1984). Even though the existence of the anomaly was pointed out some 60 years ago, it is still observable as evidenced by more recent studies (Gerard, 2012; Ke and Ramalingegowda, 2005; Sojka, 2018c).

This study is based on quarterly reports. The choice of quarterly, and not e.g. yearly reports, was prompted by the discussion about the usefulness of such reports that took place within the Polish capital market after the introduction in 2013 of the EU's Transparency Directive, which banned member states from imposing an obligation to publish quarterly reports.

The directive prohibits EU member states from imposing on companies the duty to publish interim reports which are more frequent than half-yearly. At the same time the directive allows for an exception to this rule, i.e. the obligation to publish more frequent reports can be imposed on condition that it does not create a disproportional burden for small and medium firms. The burden of providing the additional financial information has to be proportional to the information's meaningfulness in the investment-making process (Pachucki and Plutecki, 2018).

The European Commission justified the ban by arguing that such an obligation constitutes a significant burden for small and medium companies, does not add to investors' security and at the same time discourages long-term investing (Kucharczyk, 2014).

The possibility that quarterly reports will cease to be released has led to an intense discussion about their usefulness. The market participants were generally in agreement that quarterly reports are necessary and useful, and any differences in opinions concerned merely matters like the scope or what the appropriate deadlines should be.

The market participants were not convinced by the arguments proffered by the European Commission. On the issue of investor security, the Association of Individual Investors in Poland (SII) suggested that the absence of quarterly reports could lead to a situation when the first information about the financial condition of a company would be available to investors nine months after the beginning of the fiscal year (Stowarzyszenie Inwestorów Indywidualnych, 2014). This, in turn, in view of the dynamically changing macroeconomic environment and the internal situation of companies, could lead to bad investment decisions. It would also obstruct investors in reacting in a timely manner to a significant worsening of a company's earnings or to symptoms of insufficient financial liquidity. The SII also insisted that quarterly reports do not hamper creating long-term investment strategies, in fact quite 
the opposite - they often make it easier by providing more flexibility in managing long-term positions. In respect of the supposed significant burden generated by the duty to publish quarterly reports, investors indicated that, among others, companies would still have to prepare quarterly reports for their own internal use, that quarterly reports are not subject to audit which significantly lowers the related costs, and that past experience shows that quarterly reports do not constitute an excessive burden. Moreover, the companies themselves were in favour of maintaining the duty to publish quarterly reports (Kwiatkowska, 2014).

Taking into consideration the market participants' opinion on the matter, the national legislature decided to continue with the requirement to publish quarterly reports. At the same time, as per the market participants' suggestions, the duty to publish a Q4 report was abolished and the deadlines for publishing Q1 and Q3 reports were extended.

Whereas it may seem that in Poland the discussion on the subject has run its course, at least for the time being, the subject still continues to raise controversy in other parts of the world. In 2018 President Donald Trump appealed to the US Securities and Exchange Commission (SEC) to examine whether quarterly reporting does not result in investors putting pressure on companies to focus excessively on short-term earnings at the expense of long-term growth (Edgecliffe-Johnson and Henderson, 2019). Another example is the Singapore Exchange (SGX) which, following the lead of London and Hongkong, decided to abolish the requirement for listed companies to publish quarterly reports, which was meant to save them time and money (Tan, 2020). The above very recent examples indicate that the subject is still noteworthy and relevant.

The aim of this paper was therefore two-fold. First to check whether the PEAD anomaly is present on the Polish stock market, and second, to examine the market's imminent reaction to the announcement of quarterly earnings. If the market's reaction is evident and appropriate it would suggest that market participants do in fact find quarterly reports helpful in making investment decisions. On the other hand, if no reaction was observed, it would suggest that the duty to publish quarterly reports is potentially superfluous, as suggested by the European Commission. The research should also be viewed in terms of the efficient market hypothesis. By examining PEAD, the author checked if it is possible to earn abnormal returns based on publicly available information. A positive answer to this question would argue against market efficiency in a semi-strong form.

The research was carried out using event study analysis for the period 2017-2019 on a research sample comprising of 40 companies from the WIG20, mWIG40 and sWIG80 indices. To the best of the author's knowledge this paper is only the second study dedicated to the subject of PEAD in respect of the Polish market based on analysts' forecasts rather than autoregressive models ${ }^{1}$. This change is important,

\footnotetext{
${ }^{1}$ The first was a study by Sojka (2018b).
} 
because forecasts made by analysts can reasonably be expected to be a better proxy for market expectations than autoregressive models. Therefore, the results should offer more binding implications for the practitioners who wish to take advantage of the anomaly's existence.

The remaining part of the paper was divided into two sections. The first describes the research sample and the used methodology, while the second presents and discusses the research's results. Finally, the conclusion and closing remarks are presented.

\section{Research sample and methodology}

The unequal access to information on the part of various groups of investors usually causes methodological problems when examining the impact of a selected event on share prices, as it is difficult to indicate the precise moment at which the event begins to affect the prices. For example, many stockbrokers pass on to their clients their recommendations together with reports shortly before they are officially published. Hence the market's reaction is spread over time, between the dissemination of the report to the stockbroker's clients and the dissemination to the general public (Mielcarz, 2016). This problem does not arise when examining the impact of the announcement of quarterly earnings, as the dates of publishing quarterly reports are determined by companies long in advance, and the reports themselves are disseminated in the official ESPI system, which was created with the intention to guarantee equal (simultaneous) access to information for all market participants. It is also worth mentioning that the publication of a quarterly report is preceded by a 30-day 'closed period', during which insiders are not allowed to carry out any transactions.

The presented research analysed the quarterly reports of 40 companies selected at random from the WIG20, mWIG40 and sWIG80 indices, where the fundamental criterion in the selection of companies was their satisfactory analytical coverage. The research included the period from Q3 2017 to Q2 2019, namely eight quarters.

The quarterly reports, and in particular the exact date of their publication and the reported net profit, were accessed from www.stockwatch.pl and manually gathered. The market consensus of net profit for individual companies in the individual quarters was taken from the "Konsensusy" database run by the Polish Press Agency (PAP). The database gathers all the stock recommendations concerning the Polish market, and on the basis of these, diverse indicators are calculated. Market consensus is understood as the mean value of the forecasted net profit from all the recommendations aggregated in the database, whereas only those companies that had at least three recommendations for each of the eight quarters covered by the study were included in the research sample.

Next, each event was assigned to one of the three groups, depending on the actual net profit earned by the company as compared to the market consensus. 
In the categorisation of events to groups, two methods are commonly used in papers concerning PEAD. The first one considers the simple percentage deviation of company's earnings from market consensus and the other one, commonly called SUE (standardised unexpected earnings), is a standardised version of the first. In this article the simple percentage deviation was used, and although it is a simpler method, it yields satisfactory results, as shown by MacKinlay (1997). Similarly to the study by MacKinlay, $2.5 \%$ was used as the cut off point. If the net profit was more than $2.5 \%$ above the market consensus, this was considered 'good news' for the company. Analogically, if the net income was more than $2.5 \%$ worse than expected, this was considered 'bad news' for the company. If the net income deviated less than $2.5 \%$ either way, this qualified as 'no news'. The criteria of classifying events into groups are presented in Table 1 .

Table 1. Criteria of classifying events into groups

\begin{tabular}{|l|c|c|c|}
\cline { 2 - 4 } \multicolumn{1}{c|}{} & Good News & No News & Bad News \\
\hline Deviation of net profit from consensus & $>2.5 \%$ & $2.5 \% \geq \mathrm{x} \geq-2.5 \%$ & $<-2.5 \%$ \\
\hline
\end{tabular}

Source: own elaboration.

Table 2 shows the basic descriptive statistics for the quarterly reports comprising the research sample.

Table 2. Descriptive statistics of the sample

\begin{tabular}{|l|c|c|c|}
\cline { 2 - 4 } \multicolumn{1}{c|}{} & Good News & No News & Bad News \\
\hline$\%$ of the sample & $39.7 \%$ & $23.1 \%$ & $37.2 \%$ \\
\hline Number of reports & 127 & 74 & 119 \\
\hline $\begin{array}{l}\text { Mean deviation of net } \\
\text { income from consensus }\end{array}$ & $30.4 \%$ & $0.4 \%$ & $-47.1 \%$ \\
\hline $\begin{array}{l}\text { Median deviation of net } \\
\text { income from consensus }\end{array}$ & $12.3 \%$ & $0.6 \%$ & $-21.2 \%$ \\
\hline
\end{tabular}

Source: own elaboration.

The information presented in the table suggests that analysts overestimate and underestimate company earnings with equal frequency. However, it is worth noting that the mean percentage deviation for 'bad news' is significantly higher (in absolute value terms) than for 'good news'.

In order to verify whether the stock prices react to the quarterly earnings announcements, the author conducted an event study, a method described in detail by Gurgul (2019). The period under analysis had to be long enough to allow to spot the drift and at the same time short enough to allow for more detailed analysis around the date of publication of the interim reports. Hence an event window comprised of 
$(-20,+20)$ trading sessions was deployed, the announcement date being session $(0)$. Companies are not allowed to disclose their interim reports during a trading session, therefore some companies disseminate their reports before a session starts (before 8:30), and other after the session finishes (after 17:05). Thus the exact time of the announcements needed to be recognised (before the session or after the session), which then allowed to adjust the event day $(0)$ accordingly. In cases where a report was published on a non-trading day, event day (0) was the first session after the announcement. Further on, whenever the word 'days' is used, it is short for trading days. It was not verified if the selected companies were involved in other relevant events (M\&A, scandals etc.) during the event window. The assumption was that a large enough sample will minimise the impact of any such events.

Similarly to the study by Gurgul, the individual shares' expected returns were calculated using the market model. In effect the abnormal returns for a given share were calculated using the following formula:

$$
A R_{j t}=R_{j t}-\alpha_{j}-\beta_{j} R_{m t},
$$

where: $A R_{j t}-$ abnormal return of stock $j$ on day $t, R_{j t}-$ actual return of stock $j$ on day $t, R_{m t}$ - return of market portfolio on day $t, \beta_{j}$ - beta of stock $j, \alpha_{j}-$ alfa of stock $j$.

In estimating the parameters of the model, as well as in calculating abnormal returns, daily returns were used:

$$
R_{j t}=\frac{P_{j t}}{P_{j t-1}}-1,
$$

where: $R_{j t}$ - return of stock $j$ on day $t, P_{j t}$ - closing price of stock $j$ on day $t, P_{j t-1}$ closing price of stock $j$ on day $t-1$.

The WIG index was used as the proxy for market portfolio, and the daily returns for the portfolio were calculated analogously as for shares. As in other studies concerning PEAD, it was assumed that the estimation window for market model parameters $(\alpha$ and $\beta$ ) should not overlap with the event window, hence the parameters were estimated, using the ordinary least squares method, based on daily returns during the period from 270 to 21 days preceding the earnings announcement.

The result of the research are the average abnormal returns $\overline{A R}$ calculated as a mean of all the individual stocks' abnormal returns on each day of the event window, calculated separately for the three groups. The returns were calculated as:

$$
\overline{A R}_{t}=\frac{1}{n} \sum_{j=1}^{n} A R_{j t},
$$

where: $n$-number of companies in the sample. 
Next, based on $\overline{A R}_{t}$ cumulative abnormal returns were calculated:

$$
\operatorname{CAR}\left(t_{1}, t_{2}\right)=\sum_{t=t_{1}}^{t 2} \overline{A R}_{t} .
$$

To test the null hypothesis that abnormal returns are zero, the Student's $t$-test was used. The test statistic for any event day $t$ is:

$$
t_{1}=\frac{\overline{A R}_{t}}{\hat{S}\left(\overline{A R}_{t}\right)} .
$$

For tests over longer intervals, the test statistic is:

$$
t_{2}=\operatorname{CAR}\left(t_{1}, t_{2}\right) /\left(\sum_{t=t_{1}}^{t_{2}} \hat{S}^{2}\left(\overline{A R}_{t}\right)\right)^{\frac{1}{2}} .
$$

In both cases the variance of the average abnormal returns was calculated based on the estimation window period to avoid an increase in the variance in the event window (Brown and Warner, 1985; Gurgul, 2019).

\section{Presentation of results and discussion}

First the collective results are presented, followed by those for each group separately. The collective results will be mostly discussed in terms of the PEAD anomaly, whereas the group results will focus more on the market's reaction around the announcement day. Table 3 shows the values of average abnormal returns $(\overline{A R})$ and the cumulative abnormal returns (CAR) in the event window for all three groups. Additionally, Figure 1 presents CAR for all the groups during the entire event window.

As expected, the obtained results confirm that investors react to quarterly reports if the information therein differs from what was expected, i.e. indicate an earnings surprise. What is surprising is that there is no visible drift in the 'good news' group, which suggests that the market reaction happens entirely on the day of the announcement. For the 'bad news' companies, there is a very clear downward drift in CAR throughout the entire event window. Around half of the drift occurs before the earnings announcement. This is understandable as investors can to a large extent predict what the announced earnings will be, based on previously released information like monthly earnings reports ${ }^{2}$, macroeconomic data or sector-specific statistics.

${ }^{2}$ There is no legal obligation to publish such reports, but some companies nonetheless decide to do so. These reports are unaudited, very basic, and usually contain only general information on revenue. 
Table 3. $\overline{A R}$ and CAR for the quarterly earnings announcement between Q3 2017-Q2 2019

\begin{tabular}{|c|c|c|c|c|c|c|}
\hline \multirow{2}{*}{ Event Day } & \multicolumn{2}{|c|}{ Good News } & \multicolumn{2}{|c|}{ No News } & \multicolumn{2}{|c|}{ Bad News } \\
\hline & $\overline{A R}$ & CAR & $\overline{A R}$ & CAR & $\overline{A R}$ & CAR \\
\hline-20 & $0.09 \%$ & $0.09 \%$ & $-0.19 \%$ & $-0.19 \%$ & $-0.01 \%$ & $-0.01 \%$ \\
\hline-19 & $0.06 \%$ & $0.15 \%$ & $-0.03 \%$ & $-0.22 \%$ & $-0.60 \%$ & $-0.62 \%$ \\
\hline-18 & $0.04 \%$ & $0.18 \%$ & $-0.23 \%$ & $-0.45 \%$ & $-0.10 \%$ & $-0.72 \%$ \\
\hline-17 & $-0.04 \%$ & $0.14 \%$ & $0.12 \%$ & $-0.33 \%$ & $-0.10 \%$ & $-0.81 \%$ \\
\hline-16 & $0.11 \%$ & $0.25 \%$ & $0.09 \%$ & $-0.24 \%$ & $-0.18 \%$ & $-0.99 \%$ \\
\hline-15 & $-0.06 \%$ & $0.19 \%$ & $-0.07 \%$ & $-0.30 \%$ & $-0.33 \%$ & $-1.32 \%$ \\
\hline-14 & $-0.11 \%$ & $0.09 \%$ & $0.06 \%$ & $-0.24 \%$ & $-0.28 \%$ & $-1.60 \%$ \\
\hline-13 & $-0.08 \%$ & $0.01 \%$ & $-0.18 \%$ & $-0.42 \%$ & $-0.05 \%$ & $-1.65 \%$ \\
\hline-12 & $-0.06 \%$ & $-0.05 \%$ & $0.04 \%$ & $-0.39 \%$ & $-0.15 \%$ & $-1.80 \%$ \\
\hline-11 & $-0.20 \%$ & $-0.25 \%$ & $-0.09 \%$ & $-0.48 \%$ & $-0.28 \%$ & $-2.08 \%$ \\
\hline-10 & $0.07 \%$ & $-0.17 \%$ & $0.01 \%$ & $-0.47 \%$ & $-0.18 \%$ & $-2.27 \% *$ \\
\hline-9 & $0.15 \%$ & $-0.02 \%$ & $-0.29 \%$ & $-0.76 \%$ & $-0.58 \%$ & $-2.85 \% * *$ \\
\hline-8 & $-0.20 \%$ & $-0.23 \%$ & $-0.58 \% * *$ & $-1.34 \% *$ & $-0.09 \%$ & $-2.94 \% * *$ \\
\hline-7 & $-0.08 \%$ & $-0.30 \%$ & $-0.07 \%$ & $-1.41 \% *$ & $0.20 \%$ & $-2.74 \% *$ \\
\hline-6 & $-0.16 \%$ & $-0.47 \%$ & $0.13 \%$ & $-1.28 \%$ & $-0.41 \%$ & $-3.15 \% * *$ \\
\hline-5 & $0.00 \%$ & $-0.47 \%$ & $-0.22 \%$ & $-1.50 \% *$ & $0.06 \%$ & $-3.09 \% *$ \\
\hline-4 & $-0.14 \%$ & $-0.61 \%$ & $0.03 \%$ & $-1.47 \%$ & $-0.16 \%$ & $-3.25 \% *$ \\
\hline-3 & $-0.04 \%$ & $-0.65 \%$ & $-0.15 \%$ & $-1.62 \% *$ & $-0.29 \%$ & $-3.53 \% * *$ \\
\hline-2 & $0.06 \%$ & $-0.59 \%$ & $0.00 \%$ & $-1.62 \% *$ & $-0.15 \%$ & $-3.69 \% * *$ \\
\hline-1 & $-0.10 \%$ & $-0.69 \%$ & $0.13 \%$ & $\begin{array}{l}-1.49 \% \\
\end{array}$ & $-0.01 \%$ & $-3.70 \% * *$ \\
\hline $\mathbf{0}$ & $0.88 \% * * *$ & $0.18 \%$ & $0.39 \% *$ & $-1.10 \%$ & $-1.35 \% * * *$ & $-5.05 \% * * *$ \\
\hline 1 & $0.19 \%$ & $0.37 \%$ & $0.47 \% * *$ & $-0.63 \%$ & $-0.29 \%$ & $-5.34 \% * * *$ \\
\hline 2 & $-0.07 \%$ & $0.30 \%$ & $0.03 \%$ & $-0.60 \%$ & $-0.53 \%$ & $-5.87 \% * * *$ \\
\hline 3 & $0.12 \%$ & $0.43 \%$ & $0.00 \%$ & $-0.61 \%$ & $0.08 \%$ & $-5.79 \% * * *$ \\
\hline 4 & $-0.17 \%$ & $0.26 \%$ & $-0.11 \%$ & $-0.72 \%$ & $-0.14 \%$ & $-5.93 \% * * *$ \\
\hline 5 & $-0.18 \%$ & $0.08 \%$ & $0.12 \%$ & $-0.61 \%$ & $-0.21 \%$ & $-6.15 \% * * *$ \\
\hline 6 & $-0.37 \% * *$ & $-0.29 \%$ & $-0.20 \%$ & $-0.80 \%$ & $0.07 \%$ & $-6.08 \% * * *$ \\
\hline 7 & $0.01 \%$ & $-0.28 \%$ & $0.52 \% * *$ & $-0.28 \%$ & $-0.03 \%$ & $-6.11 \% * * *$ \\
\hline 8 & $0.01 \%$ & $-0.27 \%$ & $-0.73 \% * * *$ & $-1.01 \%$ & $-0.19 \%$ & $-6.30 \% * * *$ \\
\hline 9 & $-0.12 \%$ & $-0.39 \%$ & $-0.42 \% *$ & $-1.43 \%$ & $-0.11 \%$ & $-6.41 \% * * *$ \\
\hline 10 & $-0.13 \%$ & $-0.52 \%$ & $-0.42 \% *$ & $-1.85 \%$ & $0.21 \%$ & $-6.20 \% * * *$ \\
\hline 11 & $0.02 \%$ & $-0.50 \%$ & $0.39 \% *$ & $-1.47 \%$ & $-0.06 \%$ & $-6.26 \% * * *$ \\
\hline 12 & $-0.42 \%$ *** & $-0.91 \%$ & $0.40 \% *$ & $-1.06 \%$ & $-0.19 \%$ & $-6.45 \% * * *$ \\
\hline 13 & $0.01 \%$ & $-0.91 \%$ & $-0.26 \%$ & $-1.32 \%$ & $-0.02 \%$ & $-6.47 \% * * *$ \\
\hline 14 & $-0.37 \% * *$ & $-1.28 \%$ & $0.39 \% *$ & $-0.94 \%$ & $-0.59 \%$ & $-7.05 \% * * *$ \\
\hline 15 & $-0.29 \% * *$ & $-1.57 \% *$ & $0.17 \%$ & $-0.76 \%$ & $-0.07 \%$ & $-7.12 \% * * *$ \\
\hline 16 & $0.13 \%$ & $-1.44 \%$ & $0.12 \%$ & $-0.64 \%$ & $-0.10 \%$ & $-7.22 \% * * *$ \\
\hline 17 & $-0.02 \%$ & $-1.46 \%$ & $-0.05 \%$ & $-0.69 \%$ & $-0.05 \%$ & $-7.27 \% * * *$ \\
\hline 18 & $0.37 \% * *$ & $-1.09 \%$ & $-0.08 \%$ & $-0.77 \%$ & $-0.16 \%$ & $-7.43 \% * * *$ \\
\hline 19 & $-0.51 \% * * *$ & $-1.60 \% *$ & $-0.20 \%$ & $-0.97 \%$ & $0.07 \%$ & $-7.35 \% * * *$ \\
\hline 20 & $0.37 \% * *$ & $-1.24 \%$ & $-0.03 \%$ & $-1.00 \%$ & $0.11 \%$ & $-7.24 \% * * *$ \\
\hline
\end{tabular}

$* * *, * *$ and $*$ indicate respectively statistical significance level of $1 \%, 5 \%$ and $10 \%$.

Source: own elaboration. 


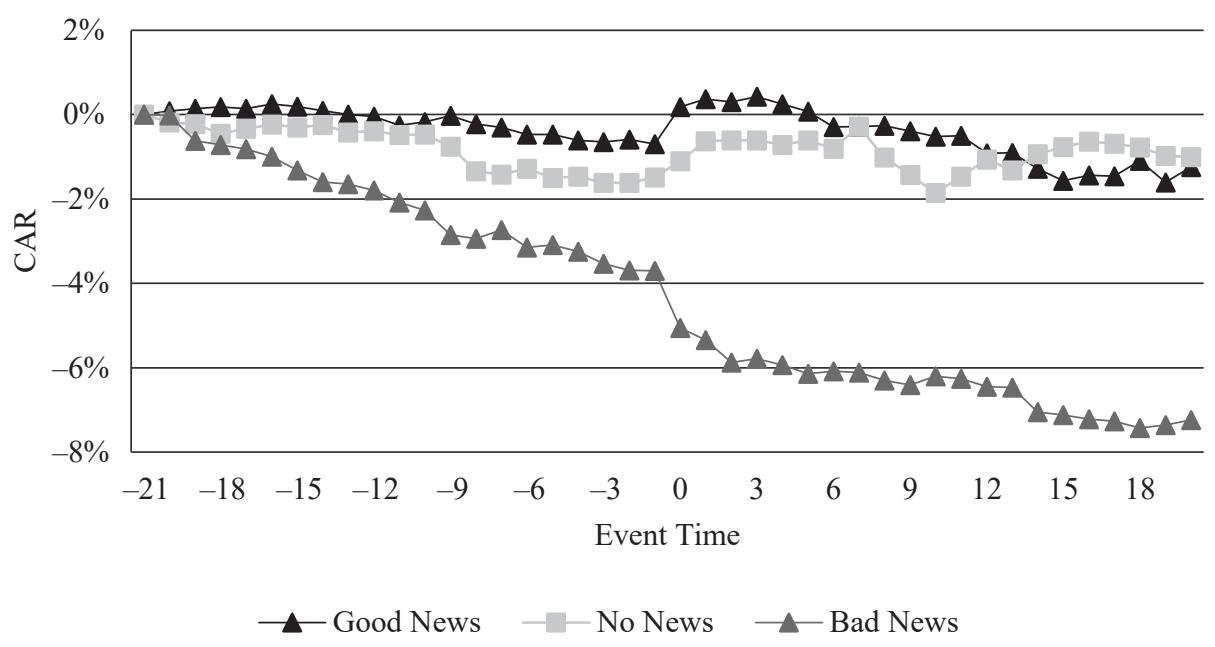

Fig. 1. CAR for quarterly earnings announcements between Q3 2017-Q2 2019

Source: own elaboration.

The results differ from those obtained for the American market by Bernard and Thomas (1989) and Foster et al. (1984). The main difference is that no drift was observed for the 'good news' companies. In regard to the 'bad news' companies, the obtained results are consistent with the above mentioned studies, although the downward drift seems to be stronger on the Polish market. The results also differ from those obtained for the Polish market by Sojka (2018a, 2018b), but are coherent with those obtained by Szyszka (2001). However, in Sojka's studies abnormal returns are calculated as simply the difference between the stock's return and the benchmark's return and hence the results of the research are better comparable to Szyszka's study, who also used the market model to estimate expected returns. The obtained results are similar to those presented by Szyszka. In both studies no statistically significant upward drift was observed in the pre-announcement $(-20,0)$ window nor in the post-announcement $(2,20)$ window. However, it is important to point out that there is some upward drift of CAR for the 'good news' companies in Szyszka's results. The bulk of it happens in the $(-60,-35)$ window, but as the author suggests himself, it is unclear if it is the investors front-running the upcoming earnings announcement, or if it is their reaction to the prior quarter earnings. For the 'bad news' companies, the CAR obtained by Szyszka in the window $(-20,20)$ amounted to $-6.4 \%$ and is similar to the $-7.2 \%$ obtained by the author. The similarity of the results between the two studies is worth emphasising given the differences in the applied methodology3.

${ }^{3}$ In the estimation of expected earnings, Szyszka used autoregression model, whereas the author used analysts' forecasts. In the categorization of events to groups, Szyszka used standardized unexpect- 
In respect of market efficiency, the obtained results meet to a greater degree the conditions posed by the efficient market hypothesis in a semi-strong form, than the results obtained by other researchers, since a drift in cumulative abnormal returns was observed only for companies that reported earnings below expectations.

\subsection{Impact of announcing quarterly earnings that were better than expected}

Figure 2 shows average abnormal returns on individual days of the event window.

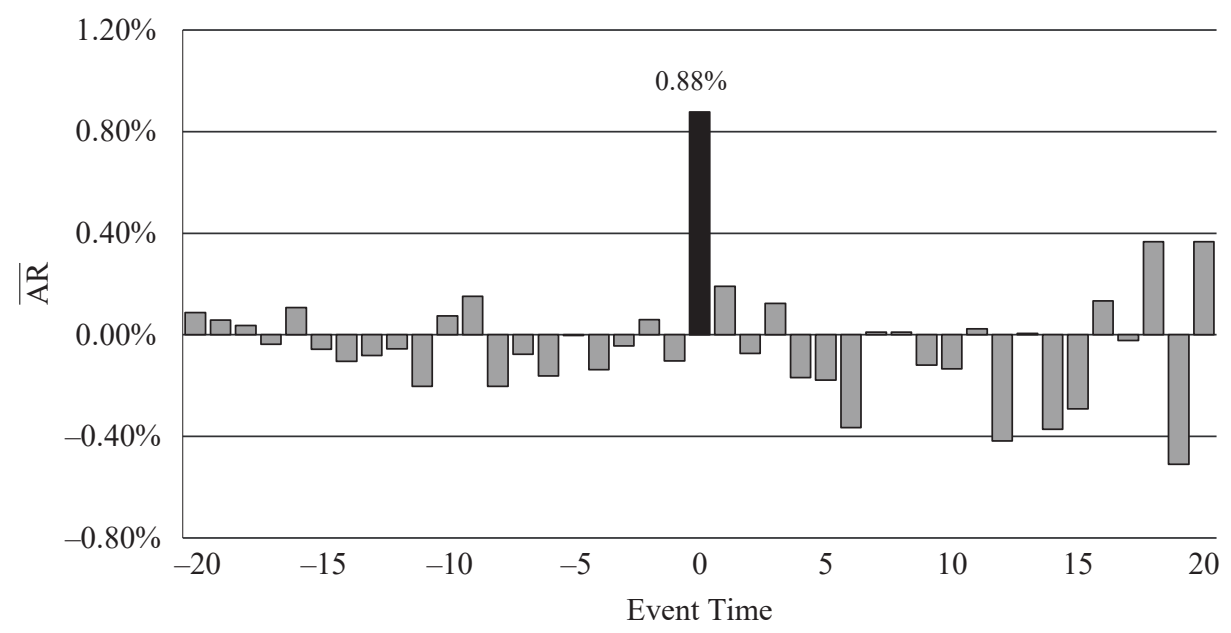

Fig. 2. Average abnormal returns $(\overline{A R})$ in the event window (Good News)

Source: own elaboration.

The market's reaction to the publication of the interim report is very clearly visible (Figure 2). The return on the day of the announcement was $0.88 \%$ above the expected, as estimated using the market model. This is the highest value of $\overline{A R}$ during the entire event window and it is statistically significant at the $1 \%$ level. The direction of the reaction is also as expected. The above points strongly suggest that the process of reflecting the unexpectedly good earnings in the stock prices is taking place, which in turn indicates that the reports are of interest and use to investors.

Figure 3 shows cumulative abnormal returns and the boundaries of statistical significance at the $5 \%$ level in the selected event windows.

No drift in cumulative abnormal returns was observed in the pre or post-announcement periods. Whereas the market is clearly interested in the fact that companies' earnings were above those expected, this information seems to be entirely reflected in the stock prices on the day of the announcement. Even on the

ed earnings, whereas the author used unstandardized unexpected earnings. There are also other, but less significant, differences between the methodologies in these two studies. 


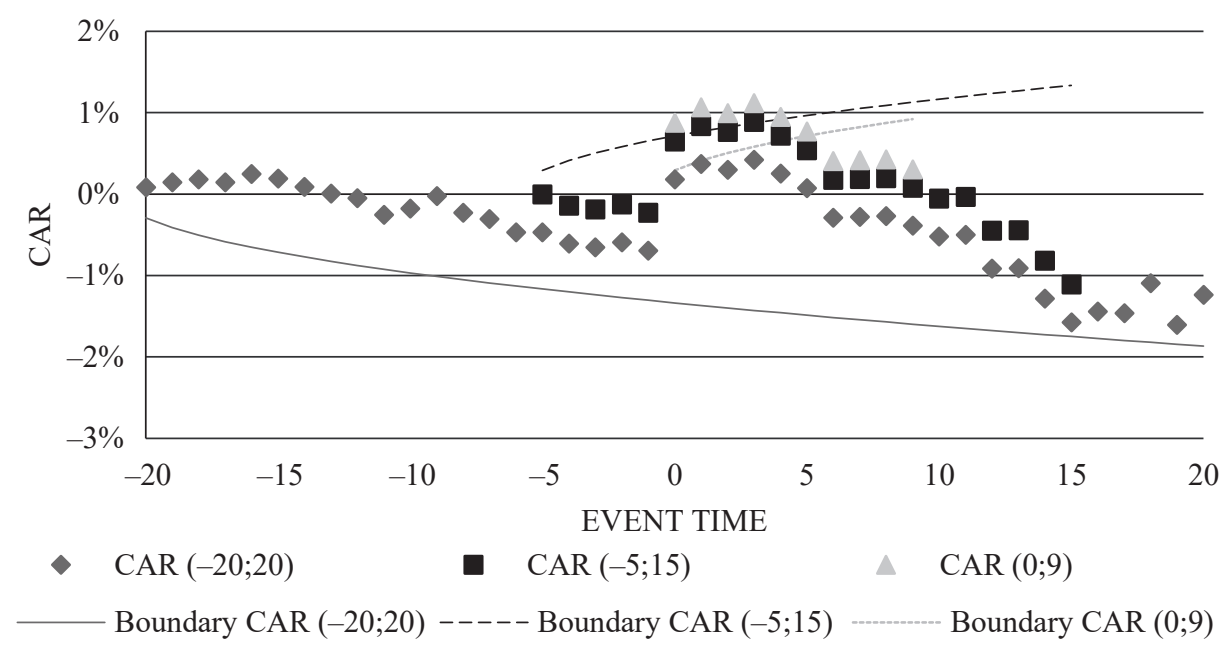

Fig. 3. Cumulative abnormal returns $(C A R)$ in the selected event windows (Good News) Source: own elaboration.

very first day after the announcement, no statistically significant value of $\overline{A R}$ was observed. In fact, the abnormal returns on the days following the announcement are very close to zero. The lack of drift in CAR during the pre-announcement period also suggests that the results present more effective reflecting of new information in stock prices. According to the mainstream of the subject literature, the cumulative abnormal returns drift in the direction of an earnings surprise for the next few months following the announcement. If so, then the drift should naturally continue to be visible in the pre-announcement period of the next quarter. If one assumes that the market has became more efficient and the information contained in the reports is reflected fully on the day of the announcement, then the drift in CAR should not be observed during either the post or the pre-announcement periods.

\subsection{Impact of announcing quarterly earnings that were worse than expected}

Figure 4 shows the values of abnormal returns on the individual days of the event window.

The negative values of $\overline{A R}$ are visible from the beginning of the event window. Yet again, the strongest reaction was seen on the day of the earnings announcement, on which the abnormal return reaches $-1.22 \%$. The $\overline{A R}$ on that day is statistically significant at $1 \%$ level, and is the only statistically significant $\overline{A R}$ in that group (see Table 3). This fact clearly indicates that investors, just as for companies with positive earnings surprise, are interested in the content of quarterly reports and make investment decisions based on the information supplied in them. 


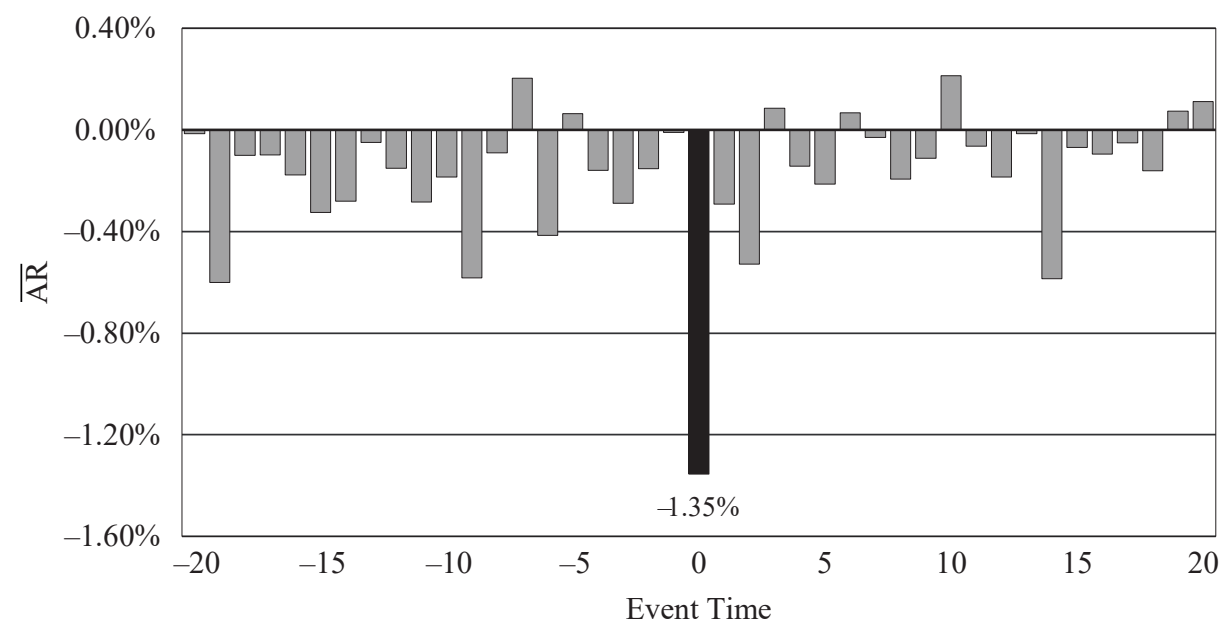

Fig. 4. Average abnormal returns $(\overline{A R})$ in the event window (Bad News)

Source: own elaboration.

Figure 5 shows cumulative abnormal returns and the boundaries of statistical significance at the $5 \%$ level in the selected event windows.

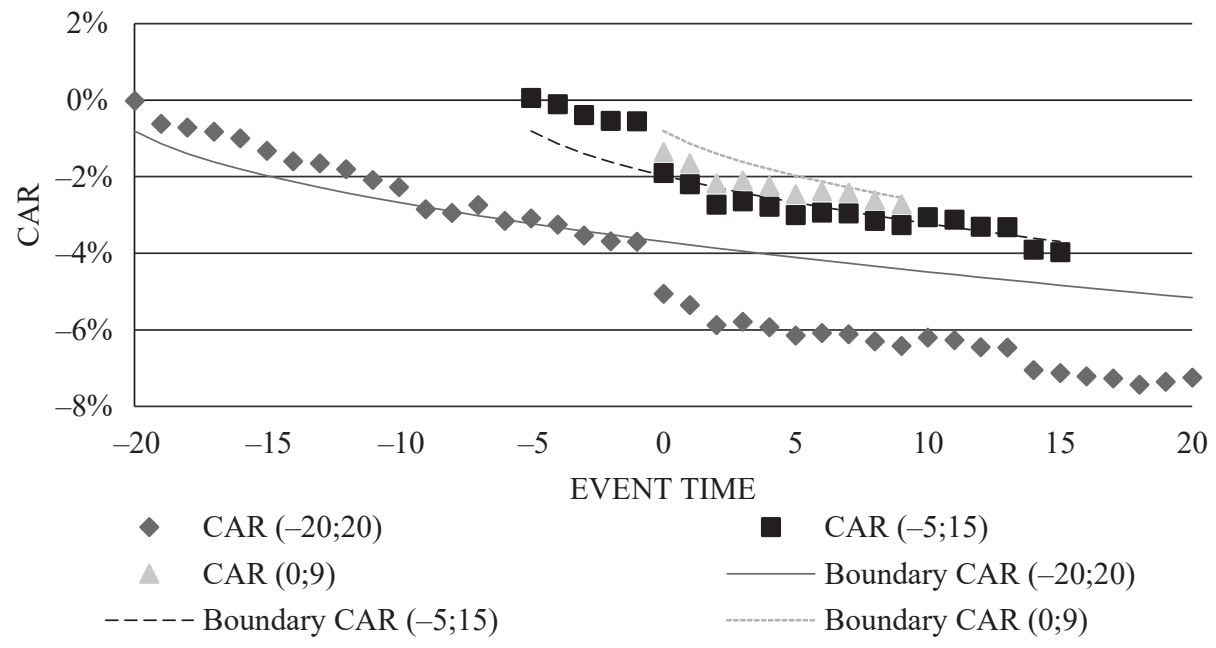

Fig. 5. Cumulative abnormal returns (CAR) in the selected event windows (Bad News) Source: own elaboration.

As opposed to the 'good news' companies, the 'bad news' group has a clearly visible trend in CAR, which begins to fall already at -20 days before the 
announcement and continues this trend up to the end of the event window. This suggests that some of the market players anticipate a deterioration in earnings and sell their shares even before the quarterly report is published. It is also worth noting that the strength of the reaction is much greater than in the 'good news' group, in terms of both CAR and $\overline{A R}$. The mean absolute value of $\overline{A R}$ for all days in the event window for 'bad news' companies amounts to as much as $0.24 \%$, whereas for the 'good news' companies it is only $0.14 \%$. Thus it can be stated that on average, the announcement of a negative earnings surprise results in a much stronger reaction than when a positive earnings surprise is announced. This potentially may be due to the fact that the mean percentage deviation of the actual earnings from the market consensus is significantly higher in the 'bad news' group (see Table 2). This is in line with the results obtained by Sojka (2018b, 2018c) and Szyszka (2001).

\subsection{Impact of announcing quarterly results that were as expected}

Figures 6 and 7 present the abnormal returns on the individual days of the event window and the cumulative abnormal returns together with the boundaries of statistical significance.

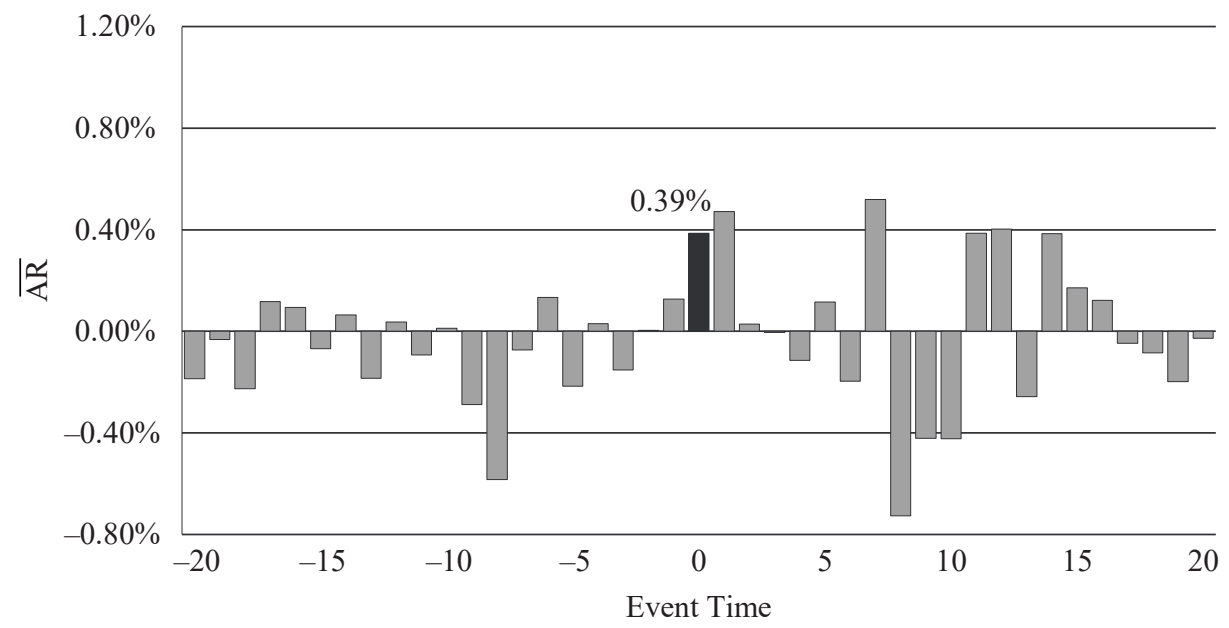

Fig. 6. Average abnormal returns $(\overline{A R})$ in the event window (No News)

Source: own elaboration.

The announcement of earnings that are in line with analysts' forecasts, results in moderate positive values of abnormal return. Contrary to the two previous groups, $\overline{A R}$ does not reach extreme values near the day of earnings announcement. Another feature that separates this group from the others is the randomness, both in terms of the direction and size of the $\overline{A R}$ on the individual days of the event window. 


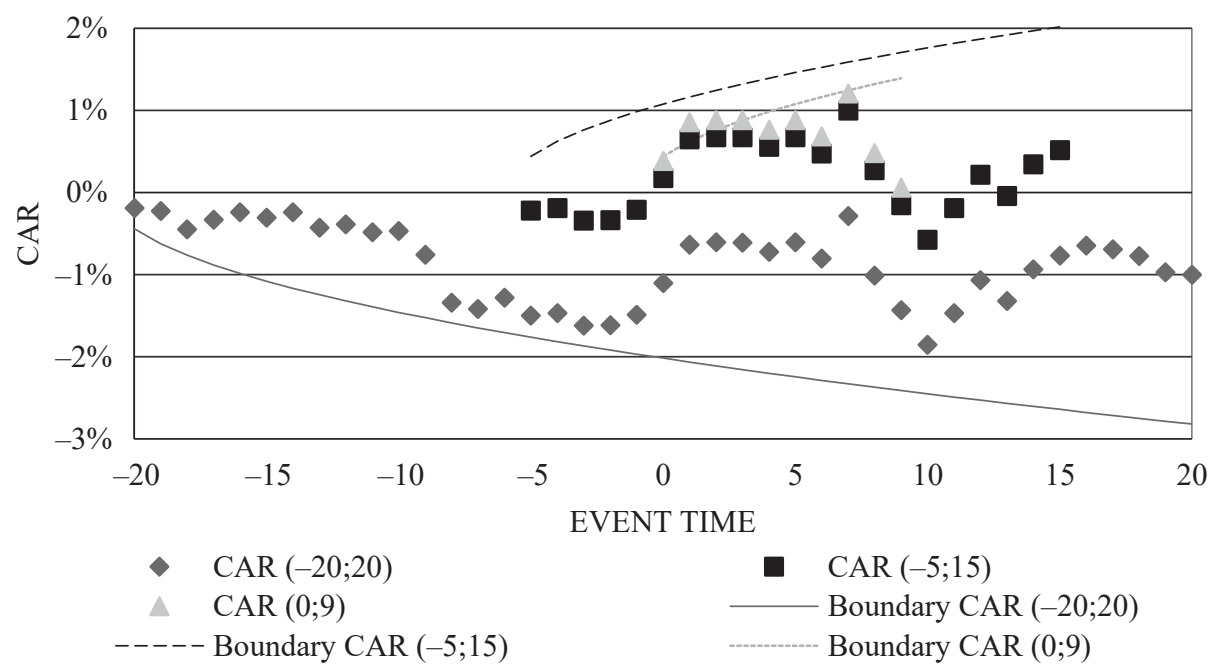

Fig. 7. Cumulative abnormal returns $(C A R)$ in the selected event windows (No News)

Source: own elaboration.

There is also no visible trend in CAR, which is in line with the expectations. As no earnings surprise is announced, the released information merely confirms that the assumptions made in the past about the companies' future profitability, were correct.

\section{Conclusion}

The obtained results show that quarterly reports provide new and valuable information given that they contain information about an unexpected change in the company's earnings. The observed reaction of investors was in line with the type of information provided by the announced earnings. On the day of the quarterly earnings announcement, stock prices of companies that reported better (worse) net income than expected earned positive (negative) abnormal returns.

In the context of the PEAD anomaly, the results can be seen as surprising. The anomaly was observed only in the group of companies that reported disappointing earnings. Contrary to the studies conducted by other researchers, the anomaly was not observed in the group of companies that reported earnings above market expectations. A potential explanation for this could be the presence of an entity whose investment strategy is based on exploiting the anomaly. However, such an explanation raises two fundamental questions: 1) why is the anomaly still present in the case of companies that reported below expectations earnings? and 2) why is such an entity not present on the US market? The answer to the first question seems to be the limited access to short selling on the Polish market. An entity wanting to benefit 
from the existence of the anomaly in the group of companies that disappointed with their earnings, would have to have a continuous and broad access to securities lending, which would enable it to take short positions after the announcements. The market of securities lending is practically non-existent in Poland, which renders such a strategy impossible. The author does not have the information enabling to provide an unambiguous answer to the second question, therefore any consideration given to this subject is purely speculative. The answer may be that the individual investors comprise a much larger share of the US stock market compared to the Polish market. The mere presence of PEAD does not necessarily indicate the absence of such entities on the US market. As indicated by Taylor (2010), individual investors display a tendency to carry out transactions in the direction opposite to that suggested by an unexpected change in earnings, and their operations significantly slow down the process of reflecting the unexpected information in share prices. Hence, there is a possibility that the combined impact of individual investors on the US market is so large that such an entity is simply unable to remove the presence of the anomaly in full.

In the context of market efficiency, the obtained results meet to a greater extent the conditions posed by the semi-strong form of market efficiency than the results obtained by other researchers, as the accumulation of abnormal returns was observed only in the group of companies that announced disappointing results. Bearing in mind that there is a very limited access to short-selling on the Polish stock market, one could risk the opinion that no evidence was found against the claim that the Polish stock market is semi-strong efficient. If despite that, one insisted that the conditions of market efficiency in a semi-strong form were not met, it should be noted that the observed inefficiency most likely results from structural and regulatory reasons, and not from the inefficiency of the market and its participants as such.

The small size of the research sample was undoubtedly among the limitations of the conducted research. A sample consisting of a larger number of companies, combined with an extended period under analysis, would allow for drawing much more binding conclusions. The author would like to indicate that the existing databases provide access to a significantly larger amount of data than it was possible for the author to obtain manually, therefore the subject remains worthy of further interest.

It also seems worthwhile to return to the subject when the Warsaw Stock Exchange (WSE) launches its short-selling platform, whose introduction belongs among the strategic targets presented in the WSE\#2022 strategy (Rudke, 2019). This will allow to verify the hypothesis postulated by the author that the presence of the anomaly in the group of companies that disappointed with their earnings is due to the lack of widespread access to short-selling. 


\section{Acknowledgments}

I would like to express my gratitude and thank Marek Pauka, Associate Professor of the Wroclaw University of Economics and Business, for the encouragement and many invaluable and inspiring comments, without which this paper would not be possible.

\section{References}

Ball, R., and Brown, P. (1968). An Empirical Evaluation of Accounting Income Numbers. Journal of Accounting Research, 6(2), 159-178.

Bernard, V., and Thomas, J. (1989). Post-Earnings-Announcement Drift: Delayed Price Response or Risk Premium? Journal of Accounting Research, 27, 1-36.

Brown, S., and Warner, J. (1985). Using daily stock returns: The case of event studies. Journal of Financial Economics, 14(1), 3-31.

Edgecliffe-Johnson, A., and Henderson, R. (2019). Trump proposal to axe US quarterly reporting gets tepid reception. Retrieved from https:/www.ft.com/content/10144538-4cc2-11e9-bbc9$-6917 \mathrm{dce} 3 \mathrm{dc} 62$

Foster, G., Olsen, C., and Shevlin, T. (1984). Earnings Releases, Anomalies, and the Behavior of Security Returns. The Accounting Review, 59(4), 574-603.

Gerard, X. (2012). Information Uncertainty and the Post-Earnings Announcement Drift in Europe. Financial Analysts Journal, 68(2), 51-69.

Gurgul, H. (2019). Analiza zdarzeń na rykach akcji. Łódź: Wydawnictwo Nieoczywiste.

Ke, B., and Ramalingegowda, S. (2005). Do institutional investors exploit the post-earnings announcement drift? Journal of Accounting and Economics, 39(1), 25-53.

Kucharczyk, K. (2014). Rynek boi się likwidacji raportów kwartalnych. Retrieved from https://seg.org. $\mathrm{pl} / \mathrm{pl} /$ rynek-boi-sie-likwidacji-raportow-kwartalnych

Kwiatkowska, M. (2014). Inwestorzy boją się likwidacji obowiązu publikacji kwartalnych raportów finansowych. Retrieved from https://forsal.pl/artykuly/784772,kwartalne-raporty-finansoweinwestorzy-boja-sie-likwidacji-obowiazku-publikacji.html

MacKinlay, C. (1997). Event Studies in Economics and Finance. Journal of Economic Literature, 35(1), 13-39.

Mielcarz, P. (2016). Krótkookresowy wpływ rekomendacji na rynek giełdowy w Polsce. Warszawa: Wydawnictwo Naukowe PWN.

Pachucki, M. and Plutecki, A. (2018). Jak prawidłowo wypetniać obowiazki informacyjne. Warszawa: Komisja Nadzoru Finansowego.

Rudke, M. (2019). Jest szansa na rozwój krótkiej sprzedaży. Retrieved from https://www.parkiet.com/ Analizy/303059944-Jest-szansa-na-rozwoj-krotkiej-sprzedazy.html

Sojka, M. (2018a). 50 Years in PEAD Research. Oxford: Bonum Quant Research.

Sojka, M. (2018b). Analysts' consensus based Post Earnings Announcement Drift (PEAD) in Polish Stock Market. Oxford: Bonum Quant Research.

Sojka, M. (2018c). Post Earnings Announcement Drift (PEAD) in Polish Stock Market. Oxford: Bonum Quant Research.

Stowarzyszenie Inwestorów Indywidualnych. (2014). Stanowczy sprzeciw SII wobec likwidacji raportów kwartalnych. Retrieved from https://www.ncbiuletyn.pl/czytaj/1776-stanowczy-sprzeciw-siiwobec-likwidacji-raportow-kwartalnych.html 
Szyszka, A. (2001). Wpływ ogłoszeń kwartalnych raportów finansowych na kursy akcji notowanych na $G P W$. Poznań: Akademia Ekonomiczna w Poznaniu.

Tan, S. (2020). Quarterly reporting rule scrapped for most firms as SGX revamps disclosure regime. Retrieved from https://www.straitstimes.com/business/companies-markets/quarterly-reportingrule-scrapped-for-most-firms-as-sgx-revamps

Taylor, D. (2010). Individual Investors and Corporate Earnings. Stanford: Stanford University.

\section{WPLYW UJAWNIENIA WYNIKÓW KWARTALNYCH NA NOTOWANIA SPÓŁEK GIEŁDOWYCH}

Streszczenie: Anomalia dryfu poogłoszeniowego (post-earnings-announcement-drift - PEAD) jest jedną z najdłużej występujących anomalii rynkowych, która swoim istnieniem zaprzecza występowaniu efektywności rynku w formie półsilnej. Celem pracy było sprawdzenie, czy anomalia występuje na GPW w Warszawie oraz zbadanie wpływu ujawnienia wyników kwartalnych spółek na ceny ich akcji. Autor przeprowadził badania, które objęły okres 2017-2019, z wykorzystaniem metodyki analizy zdarzeń. W przeciwieństwie do większości badaczy autor nie znalazł dowodów na występowanie anomalii w grupie spółek, które zaraportowały wyniki powyżej oczekiwań rynku. Występowanie anomalii zostało zaobserwowane jedynie w grupie spółek, które osiągnęły wyniki poniżej oczekiwań. Zdaniem autora taki stan rzeczy może wynikać z ograniczonej dostępności krótkiej sprzedaży, co uniemożliwia uczestnikom rynku zastosowanie strategii inwestycyjnej, która wykorzystywałaby istnienie anomalii, co doprowadziłoby zarazem do jej wyeliminowania.

Słowa kluczowe: efektywność rynku, wyniki kwartalne, dryf poogłoszeniowy, PEAD, Giełda Papierów Wartościowych w Warszawie, GPW. 